\title{
A Study to Assess the Anxiety Level among People Residing in Various Parts of Assam during COVID- 19 Pandemic: A Web-Based Cross-Sectional Study
}

\author{
Namita Chetri ${ }^{1}$, June Chiring ${ }^{2}$ \\ ${ }^{1}$ Senior Nursing Faculty (M.Sc Community Health Nursing), \\ ${ }^{2}$ Nursing faculty (M.Sc Obstetrics and Gynaecological Nursing), \\ VKNRL School of Nursing, Ponka Grant, Bhisnupur, Numaligarh, Dist-Golaghat (Assam), Pin-785699
}

Corresponding Author: June Chiring

\begin{abstract}
COVID-19 pandemic is seen to create a panic situation among the people, keeping mental health at stake. Therefore monitoring the mental health during such crisis is an immediate priority. The purpose of this study was to assess the anxiety level among people residing in various parts of Assam during the COVID-19 pandemic. The objective of the study is to find the level of anxiety among the people and also to find the association between the demographic data. A total of 150 people living in Assam participated in this cross-sectional web-based study. A standardized anxiety related questions based on (coronavirus anxiety scale) was generated using the Google Form, and the link was shared through social media- WhatsApp. Data collection was done within 5 days by the Google form. The result was analyzed using both descriptive and inferential statistics. Among 150 people $43.3 \%$ is the highest who have mild anxiety, $12.7 \%$ have moderate anxiety, $3.3 \%$ have severe anxiety and $40.7 \%$ have no anxiety. The chi square indicates that there is a significant relationship between anxiety and age of the respondents (Chi-square with 3 degree of freedom $=33.3946, \mathrm{p}<0.05^{*}$ ) and the age group of 25-34 years have the highest level of anxiety. It is expected that both the government and the people together can fix this pandemic and reduce the anxiety level.
\end{abstract}

Keywords: COVID-19; Anxiety; pandemic; cross-sectional web-based study; coronavirus anxiety scale; mental health.

\section{INTRODUCTION}

Anxiety is a normal phenomenon, which is characterized by a state of apprehension or uneasiness arising out of anticipation of danger. ${ }^{[1]}$ COVID-19 also made people anxious about the current situation.

COVID-19 started in December 2019 , like a viral outbreak in Wuhan city of central Hubei province of china (Holshue et al. 2020). World health organization (WHO) along with Chinese authorities started working together and the etiological agent was soon established to be a new virus was named as Novel coronavirus(2019- nCov). ${ }^{[2]}$

On $11^{\text {th }}$ January 2020 china announced its first COVID-19 related death of a 61 year old man, exposed to sea food market (WHO, 2020a). over a period of weeks the infection spread across the globe in rapid space (WHO, 2020b). ${ }^{[3]}$ On the $11^{\text {th }}$ March, WHO declared COVID-19 a pandemic as by then 114 countries were affected (WHO,2020c). ${ }^{[4]}$

Novel coronavirus disease (COVID19) has spread throughout the whole world. This phenomenon has led to a massive public reactions; the media has been reporting continuously across borders to keep all informed about the pandemic situation. All these things are creating a lot of concern for people leading to heightened levels of anxiety. Pandemics can lead to heightened levels of stress; Anxiety is a 
common response to any stressful situation. This study attempted to assess the anxiety among adult Assam population during the COVID-19 pandemic. ${ }^{[5]}$

Meanwhile, India reported its first coronavirus on $30^{\text {th }}$ January 2020 in the state of Kerala. The affected person had travel history from Wuhan, China. At present total cases of India are-1,531,783 where 34,224 person are death and 988,583 persons were recovered. ${ }^{[6]}$

Also the first case of Assam was reported on $31^{\text {st }}$ March 2020, the person detected was a 55 year old man from Silchar, he had a travel history from Delhi and stayed near the Nizamuddin area. Till now the government has confirmed a total of 33,576 positive cases including $25,402 .{ }^{[7]}$

\section{MATERIALS AND METHODS}

Study Design: Descriptive cross-sectional study

Study Setting: Various parts of Assam.

Study Population: Both male and female above 18 age group

Sample Size: 150
Sampling Technique: Snowball sampling technique

Tools used in the study: Data collection was done online with Google form

Tool 1: Contains the items of demographic characteristics of people comprising age, address, education, occupation, community, area-rural or urban, marital status.

Tool II: Self structured anxiety scale or modified standardized anxiety scale (Coronavirus Anxiety Scale). ${ }^{[8]}$

\section{Data Collection Procedure}

Data was collected from $16^{\text {th }}$ august 2020 to $20^{\text {th }}$ august 2020 from different parts of Assam. A Google form of questionnaire was created using the CAS (Coronavirus Anxiety Scale) and circulated through the WhatsApp, on receiving and clicking the link, the participants got auto directed to the information about the study and informed consent. After their acceptance to take the survey they filled up the answer. The responses were directly collected in the Google form itself and we kept 5 days to get total 150 response.

\section{Analysis and Findings}

Table 1.1: Distribution of people residing in various parts of Assam to their demographic variables $N=150$

\begin{tabular}{|c|c|c|c|c|}
\hline Sl. No. & Demographic Variables & Categories & Frequency & $\%$ \\
\hline \multirow[t]{4}{*}{1.} & \multirow[t]{4}{*}{ Age In Years } & $18-24$ years & 46 & $30.7 \%$ \\
\hline & & $25-34$ years & 83 & $55.3 \%$ \\
\hline & & $35-44$ years & 12 & $8 \%$ \\
\hline & & 45 and above & 9 & $6 \%$ \\
\hline \multirow[t]{2}{*}{2.} & \multirow[t]{2}{*}{ Gender } & Male & 50 & $33.3 \%$ \\
\hline & & Female & 100 & $66.7 \%$ \\
\hline \multirow[t]{4}{*}{3.} & \multirow[t]{4}{*}{ Education } & High School & 01 & $0.7 \%$ \\
\hline & & Middle School & 01 & $0.7 \%$ \\
\hline & & Higher Secondary School & 23 & $15.3 \%$ \\
\hline & & Graduate And Above & 125 & $83.3 \%$ \\
\hline \multirow[t]{4}{*}{4.} & \multirow[t]{4}{*}{ Occupation } & Service & 80 & $53.4 \%$ \\
\hline & & Business & 11 & $7.3 \%$ \\
\hline & & Farmer & 2 & $1.3 \%$ \\
\hline & & Others ( Housewife, Students etc) & 57 & $38 \%$ \\
\hline \multirow[t]{4}{*}{5.} & \multirow[t]{4}{*}{ Religion } & Hindu & 133 & $88.7 \%$ \\
\hline & & Christian & 7 & $4.7 \%$ \\
\hline & & Muslim & 8 & $5.3 \%$ \\
\hline & & Others & 2 & $1.3 \%$ \\
\hline \multirow[t]{2}{*}{6.} & \multirow[t]{2}{*}{ Area } & Rural & 66 & $44 \%$ \\
\hline & & Urban & 84 & $56 \%$ \\
\hline \multirow[t]{3}{*}{7.} & \multirow[t]{3}{*}{ Marital Status } & Married & 49 & $32.7 \%$ \\
\hline & & Single & 100 & $66.7 \%$ \\
\hline & & Divorced & 1 & $0.6 \%$ \\
\hline
\end{tabular}

FROM TABLE 1.1: It is evident that, majority of the people $83(55.3 \%)$ were in the age group 25-34 years and are female whose maximum education were graduate and above 125(83.3\%). Most of the people occupation was service $80(53.4 \%)$ where 
Namita Chetri et.al. A study to assess the anxiety level among people residing in various parts of Assam during COVID-19 pandemic: a web-based cross-sectional study

majority $133(88.7 \%)$ were Hindu and belong to urban $84(56 \%)$ area with most of the single ladies $100(66.7 \%)$ have the highest anxiety level.

Table 1.2: Frequency and percentage distribution of respondents on anxiety level during covid-19 $\quad N=150$

\begin{tabular}{|l|c|c|}
\hline \multicolumn{1}{|c|}{ Anxiety Level } & Frequency & Percentage \\
\hline No Anxiety & 61 & $40.7 \%$ \\
\hline Mild Anxiety & 65 & $43.3 \%$ \\
\hline Moderate Anxiety & 19 & $12.7 \%$ \\
\hline Severe Anxiety & 5 & $3.3 \%$ \\
\hline Total & $\mathbf{1 5 0}$ & $\mathbf{1 0 0 \%}$ \\
\hline
\end{tabular}

\section{anxiety level of people}

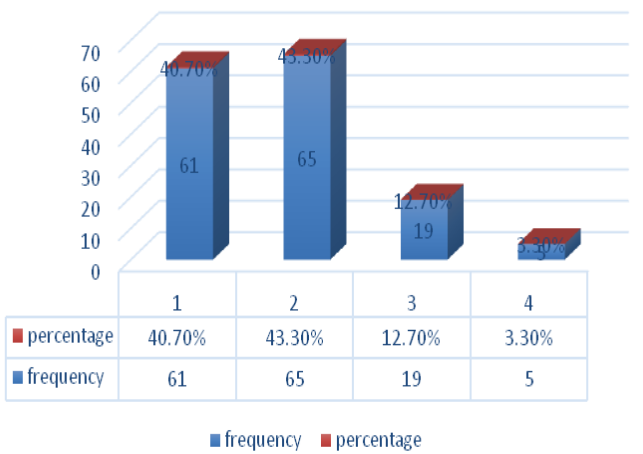

Figure 1.2: Distribution of anxiety level of people residing in various parts of Assam

Table 1.3: Association between anxiety level among the people during COVID-19 and the selected demographic variables $N=150$

\begin{tabular}{|c|c|c|c|c|c|c|c|}
\hline \multirow[t]{2}{*}{ Variables } & \multicolumn{4}{|c|}{ Anxiety } & \multirow[t]{2}{*}{$\mathbf{X}^{2}$} & \multirow[t]{2}{*}{ df } & \multirow[t]{2}{*}{$P$ value } \\
\hline & No anxiety & $\begin{array}{c}\text { Mild } \\
\text { anxiety }\end{array}$ & $\begin{array}{l}\text { Moderate } \\
\text { Anxiety }\end{array}$ & $\begin{array}{l}\text { Severe } \\
\text { anxiety }\end{array}$ & & & \\
\hline Age In Years & & & & & \multirow[t]{5}{*}{33.3946} & \multirow[t]{5}{*}{3} & \multirow{5}{*}{$\begin{array}{c}<0.000^{*} \\
\text { Sig }\end{array}$} \\
\hline a) $18-24$ years & 26 & 16 & 26 & 0 & & & \\
\hline b) $25-34$ years & 35 & 43 & 35 & 2 & & & \\
\hline c)35- 44 years & 9 & 3 & 9 & 0 & & & \\
\hline d)45 and above & 6 & 1 & 6 & 3 & & & \\
\hline Gender & & & & & \multirow[t]{3}{*}{0.6612} & \multirow[t]{3}{*}{3} & \multirow{3}{*}{$\begin{array}{c}0.882 \\
\text { NS }\end{array}$} \\
\hline A)Male & 27 & 20 & 6 & 1 & & & \\
\hline B) Female & 49 & 43 & 13 & 4 & & & \\
\hline Education & & & & & \multirow[t]{5}{*}{8.5635} & \multirow[t]{5}{*}{3} & \multirow{5}{*}{$\begin{array}{c}0.478 \\
\text { NS }\end{array}$} \\
\hline A)High School & 1 & 0 & 0 & 0 & & & \\
\hline B)Middle School & 1 & 0 & 0 & 0 & & & \\
\hline C)Higher Secondary & 58 & 58 & 15 & 5 & & & \\
\hline D)Graduate and above & 16 & 5 & 4 & 0 & & & \\
\hline Occupation & & & & & \multirow[t]{5}{*}{8.9798} & \multirow[t]{5}{*}{3} & \multirow{5}{*}{$\begin{array}{c}0.439 \\
\text { NS }\end{array}$} \\
\hline A)Service & 7 & 4 & 0 & 7 & & & \\
\hline B)Business & 2 & 0 & 0 & 2 & & & \\
\hline C)Farmer & 32 & 21 & 8 & 32 & & & \\
\hline D)Others (Housewife, Students etc) & 35 & 38 & 11 & 35 & & & \\
\hline Religion & & & & & \multirow[t]{5}{*}{1.6324} & \multirow[t]{5}{*}{3} & \multirow{5}{*}{$\begin{array}{c}0.331 \\
\text { NS }\end{array}$} \\
\hline A)Hindu & 57 & 55 & 17 & 4 & & & \\
\hline B)Muslim & 2 & 4 & 1 & 1 & & & \\
\hline C)Christian & 2 & 4 & 1 & 0 & & & \\
\hline D)Others & 0 & 2 & 0 & 0 & & & \\
\hline Area & & & & & \multirow[t]{3}{*}{2.6614} & \multirow[t]{3}{*}{3} & \multirow{3}{*}{$\begin{array}{c}0.447 \\
\text { NS }\end{array}$} \\
\hline A)Rural & 38 & 23 & 9 & 2 & & & \\
\hline B)Urban & 38 & 40 & 10 & 3 & & & \\
\hline Marital Status & & & & & \multirow[t]{4}{*}{3.7613} & \multirow[t]{4}{*}{3} & \multirow{4}{*}{$\begin{array}{c}0.474 \\
\text { NS }\end{array}$} \\
\hline A)Married & 18 & 23 & 6 & 2 & & & \\
\hline B)Single & 43 & 41 & 13 & 3 & & & \\
\hline C)Divorce & 0 & 1 & 0 & 0 & & & \\
\hline
\end{tabular}

\section{FROM FIGURE 1.3}

The above study reveals that there is a association between anxiety and age factor at $\mathrm{df}=3, \chi^{2}=33.3946$ and where the association between the other demographic data are not significant. Further there is no significant association between Gender, education, occupation, religion, area and marital status as indicated by $\chi^{2}$ value.

\section{RESULT}

Result showed that there was mild anxiety level (43.3\%), moderate anxiety level $(12.7 \%)$, severe is $(3.3 \%)$ and no anxiety is (40.7\%) among people residing in various parts of Assam and the highest was in the age group of 25-34 years. There is no other association with other demographic variables except age. 


\section{DISCUSSION}

The main objective of this study is to measure the levels of anxiety among the people during COVID 19 disease. However after analysing the result it is clear that $60 \%$ of the study subjects are anxious, having mild to severe symptoms of anxiety by the augmentation of COVID -19. The above study reveals that there is a association between anxiety and age factor at $\mathrm{df}=3, \chi^{2}$ $=33.3946$ and the age group of 25-34 years are the most affected one.

A similar study was done by Md. Akhtarul Islam, Sutapa Dey Barna, Hasin Raihan, et al on Depression and anxiety among university students during the COVID-19 pandemic in Bangladesh: A web-based cross-sectional survey. Around $15 \%$ of the students reportedly had moderately severe depression, whereas $18.1 \%$ were severely suffering from anxiety. The binary logistic regression suggests that older students have greater depression $(\mathrm{OR}=2.886,95 \% \mathrm{CI}=$ 0.961-8.669). It is also evident that students who provided private tuition in the prepandemic period had depression $(\mathrm{OR}=$ $1.199,95 \% \mathrm{CI}=0.736-1.952) .{ }^{[9]}$

In the present study it was found that there was no significant association between anxiety level with the occupation which is a contrast to this study on mental health implications of COVID-19 pandemic and its response in India was done by Adrija Roy, Arvind Kumar Singh and Ojaswini Bakshi to review the prevailing mental health issues through PubMed electronic database and Google scholar. The result was reported with major mental health issues among older people and frontline workers. ${ }^{[10]}$

\section{CONCLUSION}

The current situation of COVID-19 has affected the mental health of many people. This study has found that anxiety is also one of the associated factors which the people had never experienced before. People need to be made aware of self relaxation technique and self care measures for themselves and their families. Having regular healthy meals, proper sleep, ventilation of feelings can help to relief or reduce anxiety level. These are the urgent needs to prevent further deterioration of mental health status.

\section{Recommendations}

- A further comparative study can be done between COVID-19 in the year 2020 and 2021.

- Intervention studies can be done to decrease the anxiety level and to check its effectiveness.

\section{Acknowledgement: None}

\section{Conflict of Interest: None}

\section{Source of Funding: None}

\section{Ethical Approval: Approved}

\section{REFERENCES}

1. R Sreevani. A guide to mental health \& psychiatric nursing. $3^{\text {rd }}$ edition. New Delhi: Jaypee brothers medical publishers (p) ltd; 2010. Page number 172.

2. Michelle L. Holshue et.al. First case of 2019 novel coronavirus in the united states. The New England Journal of Medicine. January 31, 2020. Available from : https://www.nejm.org/doi/full/10.1056/NEJ Moa2001191

3. Wikipedia. Timeline of the covid-19 pandemic in January 2020. Available from: https://en.wikipedia.org/wiki/Timeline_of_t he_COVID-19_pandemic_in_January_ 2020

4. Domenico Cucinotta, Maurizio Vanelli. WHO declares COVID-19 a pandemic. US National library of science. 2020 Mar 19; 91(1): 157-160 Doi: 10.23750/abm. v91i1.9397. Available from: https://pubmed.ncbi.nlm.nih.gov/32191675/

5. Debanjan Banerjee. The COVID-19 outbreak: Crucial role the psychiatrists can play. Asian J Psychiatry. 2020 march 20; 50: 102014 Doi: 10.1016/j.ajp.2020.102014. Available from: https://www.ncbi.nlm.nih.gov/pmc/articles/ PMC7270773/

6. Vasanthi vara. Coronavirus in India: how the COVID-19 could impact the fast growing economy. Pharmaceutical 
technology: 2020 September 7. Available from: https://www.pharmaceuticaltechnology.com/features/coronavirusaffected-countries-india-measures-impactpharma-economy/

7. Rabi Banerjee. Assam report first COVID19 case. The week magazine: 2020 April 1. Available from: https://www.theweek.in/news/india/2020/04 /01/assam-reports-first-covid-19-case-deathtoll-rises-to-6-in-west-bengal.html

8. Sherman A.Lee, Amanda A. Mathis, Mary C. Jobe et al. Clinically significant fear and anxiety of COVID-19: A psychometric examination of the Coronavirus Anxiety Scale. US National Library of Science. 2020 May 2, 290: 113112: doi: 10.1016/j. psychres.2020.113112. Available from: https://www.ncbi.nlm.nih.gov/pmc/articles/ PMC7237368/\#: :text=The\%20present $\% 20$ study $\% 20$ examined $\% 20$ the, that $\% 20$ was $\% 2$ 0shown $\% 20$ to $\% 20$ be

9. Md. Akhtarul Islam, Sutapa Dey Barna, Hasin Raihan, et al. Depression and anxiety among university students during the COVID-19 pandemic in Bangladesh: A web-based cross-sectional survey. Plos one. 2020 August 26: Doi.org/10.7910/DVN/ N5BUJR. Available from: https:// journals. plos.org/plosone/article?id=10.1371/journal. pone. 0238162

10. Adrija Roy, Arvind Kumar Singh,Shree Mishra,et al. Mental health implications of COVID-19 pandemic and its response in India. US National Library of Science. 2020 Sep1:0020764020950769:Doi: 10.1177/002 0764020950769.Availablefrom:https://www .ncbi.nlm.nih.gov/pmc/articles/PMC746866 8/

How to cite this article: Chetri N, Chiring J. A study to assess the anxiety level among people residing in various parts of Assam during COVID-19 pandemic: a web-based crosssectional study. International Journal of Science \& Healthcare Research. 2021; 6(3): 88-92. DOI: https://doi.org/10.52403/ijshr.20210715 